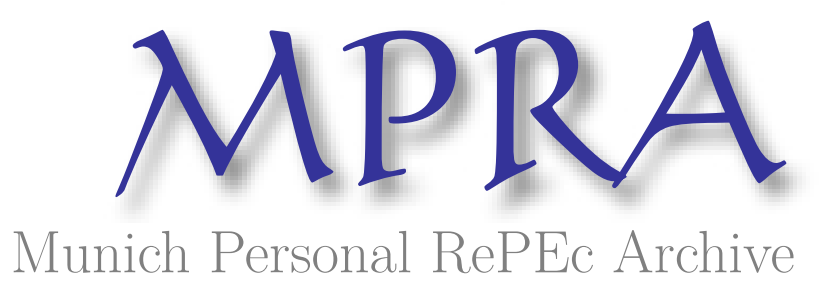

\title{
Contribution to the study of PPP arrangements in airport development, management and operation
}

Cruz, Carlos and Marques, Rui

Center of Urban and Regional Systems

25 August 2010

Online at https://mpra.ub.uni-muenchen.de/24623/

MPRA Paper No. 24623, posted 30 Aug 2010 00:37 UTC 


\title{
CONTRIBUTION TO THE STUDY OF PPP ARRANGEMENTS IN AIRPORT DEVELOPMENT, MANAGEMENT AND OPERATION
}

\author{
Carlos Oliveira Cruz \\ Center of Urban and Regional Systems (CESUR), DECivil, \\ Technical University of Lisbon \\ Avenida Rovisco Pais \\ 1049-001 Lisbon, Portugal \\ ccruz@ civil.ist.utl.pt \\ Rui Cunha Marques \\ Center of Urban and Regional Systems (CESUR), DECivil, \\ Technical University of Lisbon \\ Avenida Rovisco Pais \\ 1049-001 Lisbon, Portugal \\ rcmar@ civil.ist.utl.pt
}

\begin{abstract}
Following the liberalization wave in the airline sector, airports have been gradually taken out of the public sphere and open to the private initiative. This phenomenon is generally referred to as privatization, but not all the cases consist of, in fact, a full divestiture of assets. Although infrastructure construction, management and financing are undertaken by the private sector during a pre-defined period, usually 30 years or more, the property remains public or is transferred to the public domain after that period. This is a form of Public-Private Partnership (PPP) where two different models can be found: institutionalized PPP or a typical contractual regime, such as the concession arrangements. PPP options have been a "hot" topic over the last decade, being developed in several sectors, such as energy, water, road and seaports transportation infrastructures, etc, but few studies in the literature can be found on the PPP projects development in airport systems, for example, as far as risk-sharing is concerned. This paper looks at recent developments in airport "privatization" and "deregulation", distinguishing privatizations from PPP arrangements, through a case study approach, and establishing a comparative analysis of different PPP models used for airport management. Some comments are made about the Portuguese model and the announcement of future privatization.
\end{abstract}

Keywords: Airport Concessions; Portugal; Public-Private Partnerships; Privatization.

\section{INTRODUCTION}

Air transport has known the involvement of private companies in the provision of services, for some decades. It first started in the late 1970s, with the deregulation of the US domestic 
market, ${ }^{1}$ which allowed for a revolution in the industry, fostering the development of low cost carriers (Southwest already existed since the late 60's), increasing competition, and thus decreasing fares and stimulating traffic growth. In Europe the market deregulation only arrived in 1997, after several Packages of reform had been released (Button et al., $2005)^{2}$

The liberalization trend has moved airlines from State control and introduced a market oriented approach, focusing on clients, deciding routes on a commercial basis, instead of political arrangements between countries, and decreasing average fares. This also had impact on infrastructure providers, changing their governance models, and the market structure. In the 1980s, for example, the British government started the privatization of the British Airport Authority (BAA). At that time, the "Thatcher government" was trying to sell assets to get easy and fast money (Thatcher, 1993). Airports, unlike airlines, are an extremely profitable business, and therefore valuable, as they enjoy a monopolistic position and government protection (Bel and Fageda, 2009; Button et al., 2007).

In fact, the rationale that led the British government to sell the BAA 26 years ago is still one of the main reasons why governments proceed to divestitures in airports today: making a lot of fast money (Truitt and Esler, 1996). Worldwide, privatization of airports, similarly to the BAA, has had difficulties. In the short run, these may simply be associated with ineffective private operation and the government's loss of control of a strategic sector. In the case of Argentina and Honduras, for example, it appears that the foreign investors paid too much for the airports and were unable to fulfill the expectations and commitments assumed before the government sellers (Lipovich, 2008).

The US did not follow the world trend of privatization, and kept a public ownership model for most airports in American soil. This does not mean the absence of private participation in the airport value chain. The US model kept the asset (airport site) in the public ownership sphere and allowed for private investment in terminals and other facilities inside the airport perimeter (Fuhr and Beckers, 2009). It basically disaggregated the air and the land side, unbundling the infrastructure.

These two sub-systems have completely different characteristics. One may argue that the air side (runways, taxiways and parking stands) may be seen as a natural monopoly (with a public service obligation: allowing airport access for all those companies interested in), while land side (terminals, car parking, shopping facilities, etc.) are more easily delivered under a market competition model. This model can also be found in maritime ports, under the designation of "landlord ports" (see Cruz and Marques, 2010).

\footnotetext{
${ }^{1}$ The US Airline Deregulation Act can be pointed out as the first step towards the deregulation of the entire industry (see about the airline deregulation and its consequences Good et al., 1993)

2 The First Package was released in 1987, "lightning” the Air Service Agreements (ASA's); the Second Package in 1990, removing government intervention in air fares and facilitating access to markets; and the Third Package in 1991, which led to the deregulation of EU domestic market in 1997.

3 The port authority is responsible for canal access and maritime navigation, while terminal facilities are managed by private operators, competing for traffic in the same port.
} 
Under this model, many airlines have invested in terminal facilities, developing tailor-made facilities to their needs, and establishing long relationships with airports, which can also be achieved, indirectly, through vertical contracts (Barbot, 2009).

While in the airline sector the shift was towards the development of privately run firms, based on full divestitures with no intervention, direct or indirect, from governments, airport governance models are far more complex. With few exceptions, the public sector still retains some degree of participation in the infrastructure development, management, financing and/or operation, and in Europe the co-existence of private and public sectors is common (Oum et al., 2008).

It is possible to identify a variety of schemes for this involvement, though no irrefutable evidence is found on what model maximizes welfare. Standing at a point where the growing private sector participation in the airport management is unquestionable, this paper tries to look back and observe the multiple ways chosen towards that objective: increasing private sector involvement.

An overview on the private management of different air transport systems is provided as a review on the definition and rationale of PPP options, as well as a short discussion on what has been the late evolution on the use of this instrument of procurement. Some notes are also drawn about the Portuguese privatization process, which will be linked to the construction of the new Lisbon Airport, the largest brand new airport to be developed in Europe for the years to come.

\section{PRIVATE SECTOR PARTICIPATION IN THE AIR TRANSPORT VALUE- CHAIN}

\subsection{Non-infrastructure related activities}

Before discussing the existing models for private involvement in airport infrastructure management, a brief overview will be made on the private participation in other noninfrastructure related activities. The air transport value-chain can be divided into several segments, but the most recognizable elements by passengers are the airlines and the airports. Nevertheless, according to each airport model, several other agents can be found, such as ground handling companies, retailers (commercial areas inside airports), catering companies, car-parking operators, airplane maintenance, cleaning and security in terminal areas, among others (Ashford et al., 1997). Some of these activities are internalized by the airport manager or by the airline, like the ground handling. In some cases, specific companies were created by the airport/airline to develop ground handling activities. For example, Fraport, the airport manager in Frankfurt, has been widening its business to areas such as: ground handling and logistics, real-estate, security, advertising, consulting, etc. In Lisbon airport there are two handling companies performing in the airport, one is owned by the national carrier TAP (GroundForce), and the other by the airport manager ANA (Portway). Private sector participation in handling services in European Airports was 
possible due to the Directive 96/67/EC, under the auspices of an increase in efficiency and social welfare.

The objectives are yet to prove, but there is a clear trend to the increase of private capital in these firms, fostered by the market liberalization and changes both in the airline market and in the airport business (Tomová, 2009).

Nowadays most ground handling operators are privately run after being sold by airlines that developed a strategy of focusing on their core business. Lufthansa, American Airlines, British Midland and SN Brussels, are some examples of airlines that alienated handling activities. However, some of them retained the capacity for self-handling at the base airport. In this context, global handling firms have emerged, operating at a global scale, such as Servisair that operates in 175 airports, Swissport in 174, Worldwide in 120, Menzies in 112 and some smaller ones like AviaPartner which is present in 35 airports. ${ }^{4}$

Even Air Traffic Control Systems, which were, and still are in most countries, under public control, have been privatized. Canada privatized its air traffic control system in 1996, selling it to a private enterprise, NAV Canada. Before that, in 1987, New Zeeland Air Traffic Control (ATC) services were commercialized and nowadays they are a government corporation, with revenues coming directly from their activities (air traffic navigation and consulting activities) and directed by an independent board of directors, whose dividends are distributed to the shareholders (Betancor and Rendeiro, 1999). In this case, shareholders are public entities, the Ministers for State-Owned Enterprises and Finance. Though this is not a private company, it clearly has an organization model that allows it to work like a privately run enterprise. In the case of the UK, a PPP arrangement was established. In 2009, $46 \%$ of the capital of the National Air Traffic System, Ltd., was sold to Airline Group, the chosen partner, and 5\% to the staff, creating a mixed (public and private) firm. ${ }^{5}$

On the non-aeronautical activities group, the private participation is even deeper. The liberalization and the increasing pressure by airlines and governments to cut aeronautical taxes forced airports to explore new sources of revenue - non-aeronautical revenues (single-till principle). In most, if not all, the largest international airports, non-aeronautical revenues have accounted for more than $50 \%$ of all airport revenues (Freathy, 2004). These activities are essentially retail, real-estate development and car parking.

The airport authority (public or private) may develop these activities on a stand-alone basis, but this is becoming less common. Especially in retailing, where large groups have been specializing and operating at a global scale (for example: Westfield Airport Retail or Hochtief AirPort Retail). These groups, and others of smaller dimension, can operate at the airport site under concession and joint ventures arrangements. In the first case, the airport authority works like a landlord, awarding the retail activities for which the private partner pays a fee. This concession period can vary between 1 and 10 years, and the fees paid can

\footnotetext{
${ }^{4}$ Data collected from the companies websites on June 2010.

${ }^{5}$ For more information on ATC commercialization, see Button (2005).
} 
range from $5 \%$ to $45 \%$ of the net profit (Fuhr and Beckers, 2009). Examples of flat fee models, where a fixed, pre-determined amount is set between the concessionaire and the landlord can also be found. Management contracts option, based on the principle that a party will manage the business on behalf of the authority, is also an arrangement used. The BAA, in the late 90's, changed its duty-free business from a concession to a management contract type (Fuhr and Beckers, 2009).

\subsection{Infrastructure related activities}

Regarding infrastructure development, there is a wide portfolio for private sector involvement schemes. On the one hand, the private sector may only be contracted to perform civil works under government specifications, also known as public work contracts, for which it receives a fixed sum, assuming only the risk inherent to construction. On the other hand, the government may sell an asset and the private sector will operate, manage, develop and finance that infrastructure in order to meet quality standards, usually determined by a regulator, which is called divestiture or privatization. Table 1 shows different arrangements for private sector involvement in infrastructure provision.

Table 1 - Models for private sector involvement in infrastructure provision

\begin{tabular}{ccc}
$\begin{array}{c}\text { Type of private sector } \\
\text { involvement }\end{array}$ & Description & $\begin{array}{c}\text { Legal } \\
\text { ownership of } \\
\text { assets }\end{array}$ \\
\hline Public Work Contracts & $\begin{array}{c}\text { Private sector only performs pre-determined tasks } \\
\text { to the service provider, with no responsibility for } \\
\text { the final service quality. }\end{array}$ & Public \\
\hline Technical Assistance Contracts & $\begin{array}{c}\text { Continuum contracts between private and public } \\
\text { sectors to ensure an adequate quality level in a sub- } \\
\text { system. }\end{array}$ & Public \\
\hline Sub-Contracting or Outsourcing & $\begin{array}{c}\text { The public sector contracts a private company to } \\
\text { ensure a certain service, for which the private } \\
\text { sector is entirely responsible. }\end{array}$ & Public \\
\hline Management Contracts & $\begin{array}{c}\text { Based on a set of objectives and targets, the private } \\
\text { sector manages the service for the "owner". }\end{array}$ & Public \\
\hline Leasing (Affermage) & $\begin{array}{c}\text { The private sector assumes at its own risk the } \\
\text { provision of the service, for which the public sector } \\
\text { pays a lease fee. It is not responsible for making } \\
\text { investments. }\end{array}$ & Public \\
\hline Concession (BOT or other & $\begin{array}{c}\text { The private sector is responsible for providing the } \\
\text { service, and also, for financing the investments } \\
\text { required. After the concession period, the assets } \\
\text { return to the public sphere. }\end{array}$ & Public \\
\hline BOO & $\begin{array}{c}\text { The same as BOT, but without the transfer at the } \\
\text { end of the period. }\end{array}$ & Private \\
\hline Divestiture & Complete transfer of assets from the public sector \\
to a private entity. & Private \\
\hline
\end{tabular}

${ }^{\mathrm{I}}$ Divestiture can be divided into divestiture by sale and divestiture by license (Guasch, 2004)

Theoretically, this categorization clarifies the different relationships established, but reality suggests a far more complex set of models, especially concerning issues like asset 
ownership, risk allocation (incentives to efficiency) and investment decisions, to name a few. The asset ownership is a key element to understand these types of models (Betancor and Rendeiro, 1999). For instance, in privatization and BOO regimes, the private firm owns ad aeternum the infrastructure, while in concession arrangements it can (or not) own the asset but only until the end of their term. In fact, the concession model that is generally referred to as a PPP of contractual type is structurally different from 'pure' privatization. Privatization involves a change in property, moving assets from the public to a private sphere. Even though the term privatization is commonly used, it does not represent the real concept behind it. For example, when Australia privatized its airports, it actually sold 50 year leases with the option to renew if certain conditions were met. Similarly, the Canadian national government privatized its major airports by leasing them to local public-private agencies operating like private firm. Other countries have privatized airports or portions of airports through concessions lasting 30 years or more, for instance Argentina, Greece, Peru, and the Philippines (Graham, 2008; Juan, 1996 and Lipovich, 2008). Risk allocation, more than an objective, should be a tool to be used by governments to foster efficiency (Dey et al., 2002; Grimsey and Lewis, 2002). Note that in traditional procurement methods or public work contracts, the private sector only deals with its own production risk, related to the construction or maintenance activity. On the opposite side, full privatization delivers all risks to the private sector, since the principle behind privatization is to deliver the service to the market. Each of these models represents an "all or nothing" perspective on risk assumption. Concessions are somewhere in between. The different types of risk in service provision (commercial, production and context) ${ }^{6}$ can be allocated to either the private or the public sector, or even, the same risk can be partially assumed by both sides (Marques and Berg, 2010). A good example is the commercial risk, where it is usual to find a coresponsibility of both the agents (Nisar, 2007). With investment decisions the framework is similar. There is no autonomy in deciding if and when new investments should be made, and there is total independence when the infrastructure is private. In concessions there is usually a capacity upper limit that, when exceeded, triggers an investment in capacity expansion. If the time remaining for the concession term is not enough to ensure the return of the investment, two paths are generally considered: at the end of the period the government pays the concessionaire the remaining non-depreciated investment, or more commonly, the concession is renegotiated being the extension to the concession term the most usual option. ${ }^{7}$

\section{PUBLIC-PRIVATE PARTNERSHIPS ARRANGEMENTS}

\subsection{Definition}

In 1992, the expression "Private Finance Initiative" (PFI) was introduced in the Autumn Statement, by the then Chancellor Norman Lamont, with the "aim of achieving closer

\footnotetext{
${ }^{6}$ These types of risk will be explained in the next section applied to airport development and management.

${ }^{7}$ See more in Guasch et al. (2006). The option for the provision of an extension to the concession term is that which causes fewer conflicts between the different stakeholeders.
} 
partnerships between the public and the private sector" (Allen, 2001). It is important to remind that its appearance in 1992, eight years after the privatization of the BAA, draws the distinction between privatization and the establishment of partnerships between public and private sectors. The sustaining principle of the initiative that still remains today was the total or partial transfer of risks inherent to public service provision to the private sector (Phang, 2007). Public service provision has been a government responsibility. The difficulty in providing the necessary capabilities (mainly capital outlays) to expand and rehabilitate infrastructures as well as to control cost overruns in the development of large scale infrastructures (Skamris and Flyvbjerg, 1997), and the need to achieve higher levels of efficiency in the management of services gave birth to a procurement model that promised to solve these questions, or at least appeared to do so. Through a single contract, the private operator is responsible for the infrastructure development and service provision throughout a long period. For that service, it receives a fee from users, and/or, a payment from the government. ${ }^{8}$

Grimsey and Lewis (2004) define PPP projects as "arrangements whereby private parties participate in, or provide support for, the provision of infrastructure, and (...) a project results in a contract for a private entity to deliver public infrastructure-based services". 9

\subsection{The rationale for PPP projects usage}

Some argue that this model allows the government to focus the scarce public resources on areas not covered by PPP projects, or that the competition and the scrutiny of the capital markets done by the private sector make the use of capital resources more effective (Guasch, 2004; Engel, 2009). PPP proponents argue that this procurement model provides higher value-for-money and boosts efficiency. Nonetheless, both these arguments lack irrefutable evidence.

What is clear is that, as Engel claims, PPP arrangements have the merit of bringing competition to infrastructure provision. ${ }^{10}$ But the "off balance sheet" status of this model, unaccountable for the public deficit calculation, lead to an abuse in the usage of this procurement methodology, to the extreme of allowing for economically impracticable projects to go forward because the government assures the return of the investor by assuming all (or most of) the commercial risk.

The premise for PPP projects usage is a significant risk assumption by the private party (Bennett and Iossa, 2006; Meda, 2007). It is due to the exposure of risk that the full potential of efficiency gains is leveraged, though risk aversion by the private sector should

\footnotetext{
${ }^{8}$ Engel et al. (2009) present several configurations for these payments: up-front payments, shadow tolls and availability payments.

${ }^{9}$ In the EU, PPP arrangements are defined as "forms of cooperation between public authorities and the world of business which aim to ensure the funding, construction, renovation, management or maintenance of an infrastructure or the provision of a service" (European Commission, 2004).

${ }^{10}$ Regarding competition in infrastructure provision, it is categorized into competition for the field, and competition in the field (Demsetz, 1968).
} 
be expected (Moles and Williams, 1995). The "protection" of some projects by the government, guaranteeing a risk-free continuum cash flow throughout the project lifespan, takes the merit the PPP model has of selecting those projects with negative NPV. The private sector ability to evaluate the projects would put them aside, focusing on those with an expected positive NPV.

\subsection{Recent evolution}

The European Investment Bank (EIB) estimated that between 1990 and 2006, more than one thousand PPP projects have been developed in Europe in a total of $€$ bn 200, and more $€ B n 73$ are planned for the years to come. The use of this procurement scheme has been growing significantly since the mid 1990s, as observed in Figure 1, but the geographical distribution of projects is not homogeneous. In fact, according to the EIB, the UK accounted for $58 \%$ of the total value, and France, Germany, Italy, Spain and Portugal accounted for further $30 \%$.

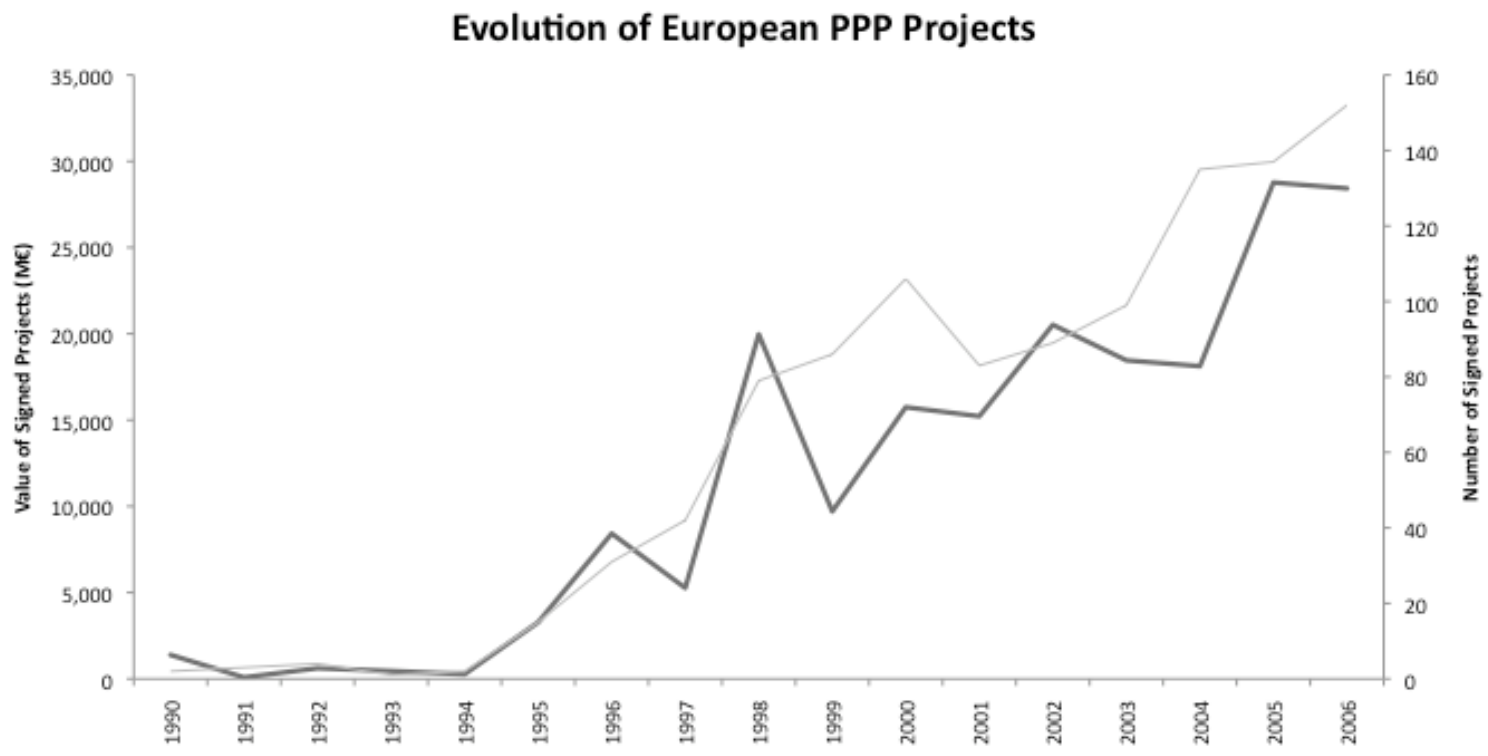

Figure 1 - Evolution of European PPP projects between 1990 and 2006 (Source: PFI Database, World Bank)

The World Bank also reported an increase in the usage of PPP arrangements, mostly financing concession arrangements which account for $60 \%$ of the total US\$Bn 30, since 1991 (see Table 2).

Table 2 - Projects with private participation financed by the World Bank (1991-2008)

\begin{tabular}{rcccccc} 
& Concession & Divestiture & $\begin{array}{c}\text { Greenfield } \\
\text { project }\end{array}$ & $\begin{array}{c}\text { Management and } \\
\text { lease contract }\end{array}$ & TOTAL \\
\hline Total number of projects & 59 & 22 & 32 & 19 & 132 \\
\hline Total investment (US \$ million) & 18,090 & 3,115 & 4,280 & 4,559 & 30,044 \\
\hline
\end{tabular}




\subsection{Types of PPP projects}

Allen (2001) presents three types of projects under the broad PFI concept: free-standing projects, joint ventures and services sold. Free-standing projects are the ones where the private sector undertakes a project, recovering the costs (and the return on the investment), through charges. Queen Elizabeth II (Dartford) or Vasco da Gama (Lisbon) bridges can be pointed out as some examples. The author argues that in cases where full cost recovery can be achieved exclusively through charges to users, there is no need for Public Sector Comparator (PSC) calculation. ${ }^{11}$ In joint venture projects the public sector contributes directly to the project, although the private sector assumes the overall control. The public sector contribution can take the form of loans or equity, transfer of existing assets, and combinations of these. Services sold, consists in activities provided by the private sector, for which the government pays a fee or rent. Hammani (2006) describes PPP arrangements according to four types: contracts, concessions, greenfields (ex: BOT) and divestitures, which is basically the same classification adopted by the World Bank. ${ }^{12}$ The European Commission classifies PPP projects into purely contractual PPP (e.g. BOT or BOOT projects) and institutionalized PPP. PPP of contractual type encompass concession and other contracts while institutionalized PPPs concern companies with mixed capital (public and private). The categorizations are not exclusive, but represent different perspectives on the arrangements. No matter what the categorization is "ventures established under PFI need to achieve a genuine transfer of risk to the private sector and secure value for money in the use of public resources" (Allen, 2001), or as HM Treasury claims "as a general rule PFI schemes should always transfer to the supplier design, construction and operating risks (both cost and performance). Demand and other risks should be a matter of negotiation with the value for money impact being tested out, where appropriate, through bids on alternative risk transfer bases against minimum and conforming requirements."

\subsection{Risk management in PPP projects}

In PPP project design and development, risk transfer and mitigation is the most critical element to successfully achieve full potential of private participation. Air transport is a particularly unstable and risky market. The high investments required, the sensitivity of revenues to macro-economic performance, and the fierce competition for routes and airports, makes it extremely difficult for airlines to recover full costs (Button et al., 2007) with great impact on airport performance.

Although several categorizations of risk can be found, the one provided by Marques and Berg (2010) is particularly useful for this analysis. The authors present a three level risk categorization as shown in Table 3.

\footnotetext{
${ }^{11}$ PSC is the project theoretical cost estimation if developed by traditional public procurement. It is used for decision makers to choose the procurement model that maximizes the project value-for-money (see more in Partnerships Victoria, 2001) and it often works as a maximum price (NPV) of the project.

${ }^{12}$ The authors, as the European literature in general, do not agree with this categorization since it is more related to the concept of private sector participation and not to PPPs. Full divestiture is not a PPP arrangement in our opinion.
} 
Table 3 - Main risks in airport development, management and operation

\begin{tabular}{|l|l|}
\hline Classification & Type of risks \\
\hline Production & $\begin{array}{l}\text { Planning, Design, Expropriation, Construction, Environmental, Maintenance and Major } \\
\text { Repairs, Operation, Technological and Performance. }\end{array}$ \\
\hline Commercial & Demand, Collection, Capacity, Competition. \\
\hline Context & $\begin{array}{l}\text { Financing, Inflation, Legal, Regulation, Unilateral Changes, Public Contestation, Force } \\
\text { Majeure. }\end{array}$ \\
\hline
\end{tabular}

Production risks in airport industry are considerable, since airports are capital intensive, both in their construction and in maintenance activities, and cost overruns in "greenfield projects" are extensively known. The most important commercial risk is demand since demand forecasts are usually wrong (De Neufville, 2003). Air transport demand has a cyclical behavior, directly linked to the economic performance curve and is very sensitive to external factors (e.g. the SARS or the HN1 flu).

Airline strategies are also of great importance when predicting traffic at the long run. For example, the hub-and-spoke strategy adopted by most airlines allows them to concentrate traffic at the main airport (hub), but if the airline is acquired by another (larger) company, or simply goes bankrupt, a significant traffic loss might happen. For instance, we can highlight the case of Zurich airport and Swissair.

Context risks in the past were usually neglected, but recently they have been on the spotlight. The financing and inflation rates were severely affected by the economic crisis that stroke the entire northern hemisphere since 2008, but more strongly, in 2010. Though the reference interest rate (established by the European Central Bank in Europe, or the Federal Reserve Bank in the US) has been decreasing to historical values, in an effort to foster the economy, the spread, or risk premium, required by the investment banks has grown to unpredictable levels. The expansion or construction of airports or airport facilities are highly capital-consuming, making marginal increases in interest rates to have a great impact on the financial balance of airport management (Costa et al., 2010).

Another context risk often neglected is force majeure. Since usually it is related to natural disaster of low, or very low, probability of occurrence, it does not seem to constitute a real menace. The "volcano crisis" that affected most Europe in the second quarter of 2010, has shown how a natural disruption can occur, with real, massive consequences on the industry. The European Commission has shown availability to allow for exceptional financial stateaid packages to the airlines, but it is still unknown how, and whether, it will be applied to airports.

\section{PPP ARRANGEMENTS IN AIRPORT BUSINESS: REVIEW OF INTERNATIONAL EXPERIENCES}

It is a fact that the private sector involvement in the airport business began with a privatization model, but has shifted towards more complex structures of PPP models, both contractual and institutionalized options. Between 1991 and 2008, the World Bank financed 
132 projects with private sector participation in airports. Almost one third of those projects (46) were undertaken in Latin America and the Caribbean, and 59 were concession arrangements, representing $60 \%$ of the total investment, as presented in Table 4.

Table 4 - Projects funded by the World Bank between 1991 and 2008 (units: US\$ million)

\begin{tabular}{|c|c|c|c|c|c|}
\hline & Concession & Divestiture & $\begin{array}{l}\text { Greenfield } \\
\text { Project }\end{array}$ & $\begin{array}{c}\text { Management and } \\
\text { Lease Contract }\end{array}$ & Total \\
\hline \multirow{2}{*}{ East Asia and Pacific } & 758 & 2,717 & 1,123 & 1 & 4,599 \\
\hline & 5 & 11 & 9 & 2 & 27 \\
\hline \multirow{2}{*}{ Europe and Central Asia } & 3,373 & 212 & 856 & 4,528 & 8,968 \\
\hline & 10 & 7 & 6 & 6 & 29 \\
\hline \multirow{2}{*}{ Latin America and the Caribbean } & 8,638 & 17 & 830 & 31 & 9,516 \\
\hline & 35 & 1 & 6 & 4 & 46 \\
\hline \multirow{2}{*}{ Middle East and North Africa } & 1,585 & 0 & 328 & 0 & 1,913 \\
\hline & 3 & 0 & 4 & 4 & 11 \\
\hline \multirow{2}{*}{ South Asia } & 3,666 & 0 & 888 & 0 & 4,554 \\
\hline & 2 & 0 & 4 & 2 & 8 \\
\hline \multirow{2}{*}{ Sub-Saharan Africa } & 70 & 169 & 255 & 0 & 495 \\
\hline & 4 & 3 & 3 & 1 & 11 \\
\hline \multirow{2}{*}{ Total } & 18,090 & 3,115 & 4,280 & 4,559 & 30,045 \\
\hline & 59 & 22 & 32 & 19 & 132 \\
\hline
\end{tabular}

Note: Numbers in italic refer to the number of projects; Source: PFI Data Base (World Bank)

European airports show a complex and, sometimes, confusing mix of private and public involvement. First, 16 out of 27 countries have some type of PPP implemented; the ones where no type was found are: Estonia, Finland, Ireland, Lithuania, Luxemburg, Poland, Portugal, Romania, Slovakia, Spain and Sweden. It is important to notice that this possibly will change in the coming years, since in some of these countries (for example, Portugal, Spain or Romania), the privatization (partial) of the airport authorities are already in the political agenda. The Portuguese case will be discussed in the next section. In those 16 countries, 7 have airports where the contractual PPP option was implemented: Bulgaria, France, Germany, Greece, Latvia, Malta and the United Kingdom. However, the institutionalized model is clearly preponderant, although different combinations were observed such as: public sector shareholder majority (e.g. France, Germany, Greece, Italy and The Netherlands) or the opposite with the majority of control by the private sector (e.g. Denmark, Belgium and Hungary).

Cases of cross-shareholding are also found, for example between Aéroports de Paris and Schiphol, where each owns a participation of $8 \%$ on the other. To ensure some level of control on airport authorities, governments often retain the power to appoint a board member in the airport authority (or more than one). This happened in Amsterdam Airport, and it can be seen as an "informal" way of regulation, though its results are far from successful. In fact, as Wit (2004) points out, the supervisory board should only be concerned with the company's best interests. By appointing a board member, the government has the "illusion" that it can influence the company's policy. At the same time, the other members of the board have the impression that "hidden" interests may exist. Although this analysis focused on the PPP option, some airports were more a public-public 
partnership, for example the airport of Munich, where different levels of governments are the only shareholders, though no data is presented regarding these schemes.

The governance models are becoming particularly complex, and the real benefit of such arrangements is ambiguous. Oum (2006) analyzing the relation between governance structures and efficiency found evidence that "airports owned and managed by a mixed enterprise with a government-owned majority is significantly less efficient than $100 \%$ publicly owned and operated airports".

These are intricate results, since most European cases are precisely a mixed presence of public and private operators, and many with public majority. This author found no statistical correlation between the most efficient airports, and those privately run. In fact, the only statistical evidence found is that where the government has the majority of the shares and combines different levels of the government (local, federal and/or central) they are the most inefficient.

\section{PRIVATIZATION OF PORTUGUESE AIRPORTS}

Portugal is one of the few countries in the world where the government still owns all the main stakeholders in the air transport sector. The Portuguese main airline, TAP, is $100 \%$ owned by the Portuguese State, through a public holding named Parpública, though the privatization of the airline has been on the public agenda for the last decade. TAP holds $100 \%$ of Groundforce, one of the two handling companies operating in Portugal. ${ }^{13}$ The other handling company, Portway, is owned by ANA Aeroportos de Portugal, the airport manager of the Portuguese airport system also fully public. All in all, the public sector owns and manages the entire Portuguese air transport value-chain. The change in this status quo is a political objective, but it is not the purpose of this paper to analyze the benefits or drawbacks of private vs. public management. At this point, the privatization of ANA is the most likely process to go forward, instead of TAP, for several reasons. The first is the need for fast revenues. The Portuguese deficit, low economic growth, and high levels of foreign indebtedness led to a decrease in the rating of the public debt, and forced the government to launch, in early 2010, a wide privatization plan. In the transport sector, ANA is the most attractive company to the private sector, due to the profit margins in the airport business able to provide large cash inflow. The second reason is the construction of the new Lisbon Airport. To tackle the congestion problem in Portela (Lisbon Airport), the government figured out to build a large, new airport, in Alcochete (50km from Lisbon), a project worth 5 billion Euros (including accessibilities).

\footnotetext{
${ }^{13}$ There are three licenses in Portugal for handling companies: GroundForce, Portway and TRIAM (operating in Madeira Airport), but the last one, went bankrupt. These licenses are given for periods between 1 and 7 years (GroundForce was given a 7 year license). For passenger handling there are more companies: Servisair, Airpasse and PTS. For licensing services, handling activities are divided into two types: ramp handling, comprising all services in the ramp or apron, such as pushback, cargo handling, water cartage, lavatory drainage, etc.; and passenger handling: check-in, gate arrival, transfer counters, just to name a few examples.
} 
Table 5 - Examples of PPP arrangements (contractual and institutionalized) in European Countries (112)

\begin{tabular}{|c|c|c|c|}
\hline Country & Airport & Type of PPP & Observation \\
\hline Austria & Vienna & Institutionalized & $\begin{array}{l}\text { Austrian airport operator of Vienna, Flughafen Wien AG, was privatized in 1992, and nowadays } 50 \% \text { of shares are in the hands of private shareholders, while the other } \\
50 \% \text { are divided between the province of Lower Austria (20\%), city of Vienna (20\%), and a private employee participation foundation }(10 \%) \text {. }\end{array}$ \\
\hline \multirow[b]{2}{*}{ Belgium } & Brussels & Institutionalized & $\begin{array}{l}\text { The Belgium government owns 25\% of the shares of Brussels Airport Company, and the remaining 75\% are owned by a private investor, the Australian Group Map } \\
\text { Airports. }\end{array}$ \\
\hline & Charleroi & Institutionalized & $\begin{array}{l}\text { The low-cost airport of Charleroi is another example of institutionalized PPP, where the Regional Authorities own } 28 \% \text { of the shares, Sowaer } 49 \% \text {, Sambrinvest } 19 \% \\
\text { (venture capital firm), Sabca (private construction company) } 1 \% \text {, and Sonaca (aerospace industry) } 1 \% \text {. The influence of the public authority in the airport management is } \\
\text { larger than the one provided by its shares, because the Regional Authority also owns } 100 \% \text { of Sowaer (a society created in } 2001 \text { to manage the financial participations of } \\
\text { the Region and manage real-estate development around the airport, and also holds } 24.15 \% \text { of Liege Airport) and } 50 \% \text { of Sambrinvest. }\end{array}$ \\
\hline \multirow[b]{2}{*}{ Bulgaria } & Burgas & \multirow[b]{2}{*}{ Contractual } & \multirow{2}{*}{$\begin{array}{l}\text { Fraport Twin Star Airport Management: At the end of year } 2006 \text { the German-Bulgarian consortium of the worldwide famous airport operator Fraport AG and the Bulgarian } \\
\text { logistic company BM Star won the competition for the concession of Varna and Burgas airports - the air gateways to the popular Bulgarian Black Sea tourist region. } \\
\text { During the 35-year concession period Fraport Twin Star Airport Management will operate and invest in the development of both costal airports. Concession contracts were } \\
\text { signed in } 2005 \text { before the beginning of the busy summer season. The 35-year contract will have an option for a 15-year extension. }\end{array}$} \\
\hline & Varna & & \\
\hline \multirow[b]{2}{*}{ Cyprus } & Larnaca & \multirow[b]{2}{*}{ Institutionalized } & \multirow{2}{*}{$\begin{array}{l}\text { Cyprus has three international airports: Larnaca, Ercan, and Paphos. Ercan airport is situated in the Turkish area of Cyprus, and is publicly run, although privatization plans } \\
\text { for increasing capacity (runway length and a new terminal building) are in the agenda. An entirely different model was developed for Larnaka and Pafos, the two largest } \\
\text { Cypriot airports, run through a 25-year concession contract, established between the consortium (Hermes Airports) and the Republic of Cyprus, in July } 2005 \text {. The } \\
\text { concession agreement included investments for the construction of a new passenger building, as well as aprons and runway extensions, which was the largest construction } \\
\text { contract done in the Republic, and was developed under a BOT scheme (622 million Euros). The shareholders structure of Hermes Airport Ltd has investors from a very } \\
\text { large diversity: the French construction group Bouygues Batiment International (22\%), the French infrastructure group Egis Projects (20\%), Cyprus Trading Corporation } \\
\text { (11.34\%), Hellenic Mining (11.33\%), Vancouver Airport Services (11\%), Aer Rianta International (11\%), Iacovou Brothers (5.665\%), Charilaos Apostolides (5.665\%) and } \\
\text { the French airport operator Aéroport Nice Cote D'Azur Chambre de Commerce et D'Industrie (2\%). One of the main shareholders (Bouggues Batiment International) was } \\
\text { responsible for all public works to update and construct facilities, subcontracting the local partners (Iacovou and Charilaos). Cyprus Trading Corporation and Aer Rianta } \\
\text { manage duty-free retailing. } \\
\text { The agreement established an annual fee of 33\% of gross revenue to the Cyprus government and a fixed annual fee of } 3.5 \text { million Euros. }\end{array}$} \\
\hline & Pafos & & \\
\hline $\begin{array}{c}\text { Czech } \\
\text { Republic }\end{array}$ & Prague & Institutionalized & Prague Airport is owned and managed by a joint stock company with the same name. \\
\hline Denmark & $\begin{array}{l}\text { Cope- } \\
\text { nhagen }\end{array}$ & Institutionalized & $\begin{array}{l}\text { The largest airport in Denmark, Copenhagen Airport, is managed by Københavns Lufthavne, a public limited company. The main shareholders are the Macquarie Group } \\
(52.4 \%) \text { and the Denmark government }(39.2 \%) \text {. Originally it was a government enterprise and was transformed into a limited company in } 1990 \text {. Four years later, the } \\
\text { government sold } 25 \% \text {, and listed the company in the Copenhagen Stock Exchange. Københavns Lufthavne also holds stocks in other airport operators, like the Newcastle } \\
\text { International Airport (where it holds 49\%), and Aeropuertos del Surest (10\%), that operates nine airports in Mexico. }\end{array}$ \\
\hline Estonia & & & No PPPs \\
\hline Finland & & & No PPPs \\
\hline \multirow{5}{*}{ France } & $\begin{array}{l}\text { Paris - } \\
\text { CDG }\end{array}$ & \multirow{2}{*}{ Institutionalized } & \multirow{2}{*}{$\begin{array}{l}\text { Aéroports de Paris is operating under a } 99 \text { year concession, and it is owned by the French government (52.1\%), the Schiphol Group (8.0\%), Caisse de Dépôts et } \\
\text { Consignations }(8.6 \%) \text {, French institutional Investors }(11.4 \%) \text {, Non-French resident institutional investors (11.4\%), French individuals and unidentified shareholders } \\
(8.6 \%) \text {, Employees }(2.1 \%) \text { and Treasury shares }(0.1 \%) \text {. }\end{array}$} \\
\hline & $\begin{array}{c}\text { Paris - } \\
\text { Orly }\end{array}$ & & \\
\hline & $\begin{array}{l}\text { Marseille } \\
\text { Provence }\end{array}$ & Contractual & $\begin{array}{l}\text { The Marseille Provence Chamber of Commerce and Industry (CCI) has managed the airport since 1934, and in } 1987 \text { the concession arrangement was renewed for a 30- } \\
\text { year period by the French State. }\end{array}$ \\
\hline & Nice & \multirow{2}{*}{ Institutionalized } & \multirow{2}{*}{$\begin{array}{l}\text { The Aéroports de la Côte d'Azur is owned by the State (60\%), the French Riviera Chamber of Commerce (25\%), and 15\% distributed equally between Region of Provence } \\
\text { Alpes Côte d' Azur, Alpes-Maritimes Regional Councils and Urban Community of Nice. }\end{array}$} \\
\hline & Cannes & & \\
\hline
\end{tabular}


Table 5 - Examples of PPP arrangements (contractual and institutionalized) in European Countries (212)

\begin{tabular}{|c|c|c|c|}
\hline Country & Airport & Type of PPP & Observation \\
\hline \multirow{3}{*}{ Germany } & Frankfurt & Institutionalized & $\begin{array}{l}\text { In Frankfurt's main airport, the manager/operator is Fraport, hold by the Sate of Hesse }(31.52 \%) \text {, the city of Frankfurt (20.13\%), and private corporations like Artio } \\
\text { Global Investors (10.35\%), Deutsche Lufthansa AG (5.01\%), Taube Hodson Stonex Partners (3.59\%), Arnhold and S. Bleichroeder Holdings, Inc. (2.98\%) and Morgan } \\
\text { Stanley (2.94\%). } 18.59 \% \text { are in the hands of anonymous shareholders. }\end{array}$ \\
\hline & $\begin{array}{c}\text { Dussel- } \\
\text { dorf }\end{array}$ & Institutionalized & $\begin{array}{l}\text { In Dusseldorf (the first German airport to be partially privatized), 50\% belongs to the Landeshauptstadt Dusseldorf (state capital) while 50\% belong to Airport Partners } \\
\text { GmbH (owned in } 40 \% \text { Hochtief AirPort GmbH, 20\% Hochtief AirPort Capital KGaA, 40\% Dublin Airport Authority plc (through its wholly owned subsidiary Aer Rianta } \\
\text { International cpt). }\end{array}$ \\
\hline & $\begin{array}{l}\text { Berlin- } \\
\text { Branden- } \\
\text { burg }\end{array}$ & Contractual & $\begin{array}{l}\text { A concession was signed, for } 99 \text { years, for Berlin-Brandenburg new airport. The winning bid belongs to IVG Holding and Hochtief Airport, together in a consortium } \\
\text { called Berlin-Brandenburg International Partner. In this greenfield project, the government role was to resettle the population in two small villages (Diepensee and } \\
\text { Selchow) and build rail and road infrastructures. }\end{array}$ \\
\hline Greece & Athens & Contractual & $\begin{array}{l}\text { Athens International Airport is commonly referred to when speaking about the PPP option in airports. Established in 1996, it was awarded the construction and } \\
\text { management of Eleftherios Venizelos airport for a } 30 \text {-year BOOT (Build-Own-Operate-Transfer) concession scheme. The company responsible for the construction and } \\
\text { operation of the airport is owned by the Greek State (55\%), while Hochtief AirPort GmbH and Hochtief AirPort Capital, owned } 26.667 \% \text { and } 13.333 \% \text { respectively, and } \\
5 \% \text { belongs to Copelouzos Group. The Airport Company is not permitted to perform any operations outside this area. Also, all of its operations are expected to be related } \\
\text { directly to the business of managing the Airport. All ground accessibility to the airport will be provided by the Greek state. }\end{array}$ \\
\hline Holland & Schiphol & Institutionalized & $\begin{array}{l}\text { Schiphol Group is the entity responsible for the management and operation of Schiphol Airport. } 69.77 \% \text { of shares belong to the Dutch government, } 20.03 \% \text { to the } \\
\text { Municipality of Amsterdam, } 2.20 \% \text { to the Municipality de Rotterdam and 8\% to Aéroports de Paris. }\end{array}$ \\
\hline Hungary & Budapest & Institutionalized & $\begin{array}{l}\text { Budapest airport is run by Budapest Airport Zrt., a company owned by the Hungarian State (25\% plus one vote), which sold in } 2007 \text { the remaining shares. Hochtief } \\
\text { AirPort became the main shareholder (37.25\%), and several financial investors acquired participations: Gic Special Investment }(13.625 \%) \text {, Caisse de depot et placement } \\
\text { du Québec (13.625\%), Aero Investment (7.5\%) and KfW IPEX-Bank (3\%). }\end{array}$ \\
\hline Ireland & & & No PPPs \\
\hline \multirow{2}{*}{ Italy } & Milano & Institutionalized & $\begin{array}{l}\text { SEA Aeroporti de Milano, controlling Linate and Malpensa airports, has the following shareholder structure: Municipality of Milan } 84.56 \% \text {, ASAM (Azienda Sviluppo } \\
\text { Acqua e Mobilitá) } 14.56 \% \text { and other minor public and private shareholders }(0.88 \%) \text {. }\end{array}$ \\
\hline & Rome & Institutionalized & $\begin{array}{l}\text { Aeriporti de Roma could be considered a private firm because the shares owned by the public sector are } 3 \% \text {, while } 95.8 \% \text { belong to Gemina (an Italian holding company } \\
\text { listed in the stock exchange market). }\end{array}$ \\
\hline Latvia & Riga & Contractual & $\begin{array}{l}\text { Riga Airport is one of the latest airports in Europe developed under a PPP scheme, in this case, a BOT agreement. The concession included the construction of a new } \\
\text { terminal and the operation of the entire airport. }\end{array}$ \\
\hline Lithuania & \multicolumn{3}{|r|}{ No PPPs } \\
\hline Luxembu. & \multicolumn{3}{|r|}{ No PPPs } \\
\hline Malta & Malta & Contractual & $\begin{array}{l}\text { Malta International Airport handled 2.9 MPax (2009), and is run by the company with the same name. In 2002, the Maltese government sold } 40 \% \text { of the } \\
\text { Malta Mediterranean Link Consortium Ltd (a } 93.6 \text { million Euros trade). In } 2002 \text { and 2005, the government sold extra } 40 \% \text { (20\% each year), to smaller }\end{array}$ \\
\hline Poland & \multicolumn{3}{|r|}{ No PPPs } \\
\hline Portugal & \multicolumn{3}{|r|}{ No PPPs } \\
\hline Romania & \multirow{2}{*}{\multicolumn{3}{|c|}{$\frac{\text { No PPPs }}{\text { No PPPs }}$}} \\
\hline Slovakia & & & \\
\hline Slovenia & Ljubljana & Institutionalized & $\begin{array}{l}\text { Aerodrom Ljubljana, the company owning and managing the Ljubljana Airport, is owned in } 51 \% \text { by the Republic of Slovenia, } 7 \% \text { by the Pension fund, } 6 \% \text { by the } \\
\text { Slovenian Restitution Fund and } 19 \% \text { by the Private Companies and other } 16 \text { legal entities. }\end{array}$ \\
\hline Spain & \multicolumn{3}{|r|}{ No PPPs } \\
\hline Sweden & \multicolumn{3}{|r|}{ No PPPs } \\
\hline \multirow[t]{2}{*}{$\begin{array}{l}\text { United } \\
\text { Kingdom }\end{array}$} & $\begin{array}{l}\text { Newcas- } \\
\text { tle }\end{array}$ & Institutionalized & $\begin{array}{l}\text { The company structure of Newcastle International Airport is the result of an agreement by the airport's seven local authority shareholders to enter into a PPP arrangement } \\
\text { with Copenhagen Airports in May 2001. As part of the establishment of a PPP arrangement for the future, the local authority shareholders sold } 49 \% \text { of its shares to the } \\
\text { Company to Copenhagen Airports and the Company has entered into a } 15 \text { year Technical Services Agreement with Copenhagen Airports. }\end{array}$ \\
\hline & Norwich & Institutionalized & Norwich International Airport is owned in $80.1 \%$ by Omniport (private investor) and the remaining shares belong to Norwich City and County Council. \\
\hline
\end{tabular}


The government decided to bundle the construction of the new airport with the sale of ANA, and so, recently, announced a single tendering procedure. The national airport network will be put on sale. To legally sustain this procedure, the government approved in April 2010, the concession basis for the airport system (Decree-Law 33/2010). This legislation grants to ANA the exclusivity of running and operating the airports in Portugal, and the obligation of building the New Lisbon Airport by 2017. One may argue about the economic rationality of constraining the future buyer decisions. In fact, the option of building or not, or when to build the new airport is eliminated, thus reducing the global economic value of ANA (see more in Costa et al., 2010). It is also questionable the creation of a monopoly in the management of the entire system. The decision of selling all airports in the same "package", forbidding the construction of new facilities in a radius of $150 \mathrm{~km}$ from each airport (deleting any future competition), maximizes the value of sale, but it is arguable that it maximizes the welfare, since for 40 years no competition will be allowed. The organization in a monopoly is also arguable. Marques (2010a) found and there is evidence that best efficiency results might be achieved if airports were independently managed. In fact, the "quiet life" and X-inefficiency arising from the lack of incentives provided by the regulator which does not have independence might have consequences in the quality of service and decrease global economic welfare, though the financial and economic indicators reveal a solid and profitable company (Marques, 2010b). The same author claims the urgency in adopting more effective regulation tools to "shake" the quiet life of ANA (Marques, 2010b). ${ }^{14}$ This decision has raised some discussions on the industry organization model for the Portuguese airport system. The process, as designed, will allow for private participation in the management of the system, but it will keep a public sector participation in the company. It is unclear at this time what will be the percentage of sale (majority vs. minority), and what will be the private sector role in the management of the firm. The regulatory model, which is key for the future of the airport sector in Portugal, is not defined and in order to add value to the privatization business it is likely that weak commitments and poor incentives are provided to the private 'entrant'. The existing market structure (only one company) demands a sound and a tighter regulation. So, major risks are also likely to be retained in the public sector with the aim of maximizing the up-front payment. Public interest might also be put at risk since exclusivity grants can jeopardize the growth and the appearance of new low-cost carriers leading them to move to other destinations and damaging the tourism which is one of the most important industries in Portugal. The example of the Airport of Athens is elucidating in this respect, since this phenomenon and type of customer was not conveniently envisaged. Finally, it should be highlighted that the business of selling ANA and the construction of the new airport, due to its size (and current worldwide financial context), possibly will not attract many bidders. Therefore, competition for the market, which is one of the major advantages of PPP arrangements, probably will not work.

\footnotetext{
${ }^{14}$ The author suggests price-cap regulation, instead of rate-of-return and the use of benchmarking tools (sunshine regulation) in addition to "carrot and stick" policies.
} 


\section{CONCLUSIONS}

Private sector participation in airport development and management is growing and it seems that it will continue to grow in a near future. Governments are facing increasing difficulties in issuing debt, and the capacity expansion and/or refurbishment works necessary to keep the international quality standards in airports will tend to be developed and financed by private entities. Unfortunately, unlike a couple of years ago, the financial sector is not so eager to finance these large investments, even with governmental guarantees, due to the difficulty of financing themselves in the international market, specially those from countries where downgrading from the rating agencies is undergoing, like Greece, Spain or Portugal. Although efficiency related arguments can be used, the main reason for PPP usage relies on the easy and faster way to get large amounts of money and/or to avoid public spending in infrastructure development. One of the boosters of privatization, the Thatcher government, did it in a time of excessive public deficit, and privatization was developed to increase income to the state budget. The latest example of Athens International Airport or the future new Lisbon Airport confirm this thesis. The Greek government was able to build an airport through a long-term concession, mainly at the expenses of private investors (and airport users), and in Portugal the privatization of ANA will allow for the construction of the new Lisbon airport. In the case of contractual PPPs, the authors found it impossible to get the contracts, or any information related to renegotiations and compensations paid by governments. The lack of transparency and public scrutiny regarding these PPP arrangements do not favor international benchmarks and the dissemination of best practices. This is a particularly relevant issue, since these long lasting contracts only happen once, creating discontinuity in the how-know. The dissemination of contract arrangements, especially as far as risk-sharing is concerned, is relevant to allow for contracts to be less incomplete. Marques and Brochado (2008) recommended the creation of a European Observatory able to deal with the airport sector heterogeneity (ownership' structures, airport characteristics -congestion, catering mainly full-service or low-cost airlines, hub or destination traffic and accounting practices) to prevent predatory practices and market power abuses, but this observatory could also perform an important role in the dissemination of best practices and monitoring of PPP arrangements in the EU area. More work is required for the development of successful partnerships. At this point, it is very difficult to evaluate the benefits of PPP arrangements in airport development. There is little information regarding both the role of each partner (public and private) in the project and risk-sharing. This is a key driver for the success of PPP projects. The "first wave" of projects developed under this procurement model was sustained on the possibility of the "off-sheet" status of this model.

\section{REFERENCES}

Allen, G., 2001. The private finance initiative (PFI). Research Paper 117, Economic Policy and Statistics Section, House of Commons Library.

Ashford, N., Stanton, H., Moore, C., 1997. Airport Operations, Sec. Ed. McGraw Hill, New York. 
Barbot, C., 2009. Vertical Contracts Between Airports and Airlines: Is there a trade-off between welfare and competitiveness? Working Paper 1, CETE, School of Economics, Oporto.

Bel, G., Fageda, X., 2009. Privatization, regulation and airport pricing: an empirical analysis for Europe. Journal of Regulatory Economics 37 (2), 142-161.

Bennett, J., Iossa, E., 2006. Building and managing facilities for public services. Journal of Public Economics 90 (10-11), 2143-2160.

Betancor, O., Rendeiro, R., 1999. Regulating Privatized Infrastructures and Airport Services. World Bank Institute, Washington DC.

Button, K., 2005. Commercialization and Deregulation: Theoretical Approaches and Lessons from Air Transportation, In 4th Conference on Applied Infrastructure Research, 8 October, Berlin.

Button, K., Costa, Á., Cruz, C., 2007. Ability to recover full costs through price discrimination in deregulated scheduled air transport markets. Transport Reviews 27 (2), 213-231.

Costa, C., Neiva, R., Santos, M. Cruz, C., 2010. Airport investment analysis in unstable markets. In Air Transport Research Society (ATRS) World Conference, 6-9 June, Oporto.

Cruz, C., Marques, R., 2010. Overview of contract arrangements in concessions: an application to seaport terminals. Working Paper, IST, Lisbon.

Demsetz, H., 1968. Why regulate utilities? Journal of Law and Economics 11 (1), 55-66.

Dey, P., Ogunlana, S., Takehiko, N., 2002. Risk management in build-operate-transfer projects. International Journal of Risk Assessment and Management 3 (2-4), 269-291.

Engel, C., Fischer, R., Galetovic, A., 2009. The basic public finance of public-private partnerships. Cowles Foundation Discussion Paper 1618, Yale University, Connecticut.

European Commission, 2004. Green paper on Public-Private Partnerships and community law on public contracts and concessions. COM 327 final, Brussels.

European Council, 1996. Directive on access to the groundhandling market at Community airports (96/67/EC of 16 October).

Freathy, P., 2004. The commercialisation of European airports: successful strategies in a decade of turbulence? Journal of Air Transport Management 10 (3), 191-197.

Fuhr, J., Beckers, T., 2009. Contracts, financing arrangements, public ownerships - an empirical analysis on the US airport governance model. Transport Reviews 29 (4), 459-478.

Good, D., Röller, L., Sickles, R., 1993. US airline deregulation: implications for European transport. The Economic Journal 103 (419), 1028-1041

Graham, A., 2008. Managing Airports: an International Perspective. Third Ed. Elsevier, Oxford.

Grimsey, D., Lewis, M., 2002. Evaluating the risks of public private partnerships for infrastructure projects. International Journal of Project Management 20 (2), 107-118.

Guasch, L., 2004. Granting and Renegotiating Infrastructure Concessions: Doing it Right. WBI Development Studies, World Bank, Washington, D.C.

Guasch, L., Laffont, J., Straund, S., 2006. Renegotiation of concession contracts: a theoretical approach. Review of Industrial Organization 29 (1-2), 55-73. 
Juan, E.J., 1996. Privatizing airports: options and case studies. Public Policy for the Private Sector, Note No.82, World Bank.

Lipovich, G., 2008. The privatization of Argentine airports. Journal of Air Transport Management 14 (1), 8-15.

Marques, R., 2010a. Together or separately? The efficiency and market structure of Portuguese airports. Forthcoming in Journal of Air Transport Management.

Marques, R., 2010b. Do the incentives in the aiport regulation matter? A case-study in Portugal. Working Paper, Technical University of Lisbon.

Marques, R., Brochado, A., 2008. Airport regulation in Europe: Is there need for a European Observatory? Transport Policy 15, 163-172.

Marques, R., Berg, S., 2009. Risks, contracts and private sector participation in water utilities. PURC Working Paper 25, University of Florida, Gainesville.

Meda, F., 2007. A game theory approach for the allocation of risks in transport public private partnerships. International Journal of Project Management 25 (3), 213-218.

Moles, P., Williams, G., 1995. Privately funded infrastructure in the UK: Participants' risk in the Skye Bridge project. Transport Policy 2 (2), 129-134.

Neufville, R., Odoni, A., 2003. Airport systems: planning, design and management. MacGraw-Hill, New York.

Nisar, T., 2007. Risk management in public-private partnership contracts. Public Organization Review 7 (1), 1-19.

Oum, T., Adler, N., Yu, C., 2006. Privatization, corporatization, ownership forms and their effects on the performance of the world's major airports. Journal of Air Transport Management 12 (3), 109-121.

Oum, T., Yan, J., Yu, C., 2008. Ownership forms matter for airport efficiency: A stochastic frontier investigation of worldwide airports. Journal of Urban Economics 64 (2), 422435.

Partnerships Victoria, 2001. Public Sector Comparator: Technical Note. Department of Treasury and Finance, Melbourne.

Phang, S., 2007. Urban rail transit PPPs: Survey and risk assessment of recent strategies. Transport Policy 14 (3), 214-231.

Skamris, M., Flyvbjerg, B., 1997. Inaccuracy of traffic forecasts and cost estimates on large transport projects. Transport Policy 4 (3), 141-146.

Thatcher, M., 1993. The Downing Street years. Harper Collins, London.

Tomová, A., 2009. PPP projects and airports: experience and state in world regions. In 8th Conference on Applied Infrastructure Research, 9-10 October, Berlin.

Truitt, L., Esler, M., 1996. Airport privatization. Policy Studies Journal 24 (1), 100-110.

Wit, J., 2004. Privatization and Regulation of Amsterdam Airport, In Forsyth, P., Gillen, D., Knorr, A., Mayer, O., Niemeier, H., Starkie, D., (Eds), The economic Regulation of Airports - Recent Developments in Australasia, North America and Europe, Ashgate, England, pp. 83-99 